International Business Management 13 (7): 241-248, 2019

ISSN: $1993-5250$

(C) Medwell Journals, 2019

\title{
Indian Corporate Debt Market-An Analysis of Developmental Challenges
}

\author{
Lovely Srivastava \\ Department of Master of Business Administration, United Group of Institution, \\ Industrial Area, Naini, Prayagraj, 211010 Uttar Pradesh, India \\ APJ Abdul Kalam Technical University Lucknow, Lucknow, India \\ 90A/3K Baghambari Gaddi Allahpur, Prayagraj, 211006 Uttar Pradesh, India
}

\begin{abstract}
Organization accomplishes their financing need through markets. Debt market is also an important source of funding for organization. A well established debt market acts as an opportunity for borrowers and investors. Indian debt market does not have that developed status as compared to developed one. It's required to develop for future growth. The objective of this research study is to identify the factors which are crucial for the development of retail corporate debt market. The study has analytical approach. Convenience sampling has been used to collect data. Liquidity is the major factor that hinders the growth and development of Indian corporate debt market. Market structure, regulatory framework, risk and return have higher degree influence on market liquidity. A developed debt market is an opportunity for the growing Indian economy.
\end{abstract}

Key words: Debt market, market structure, liquidity, investment, market determinants, economy

\section{INTRODUCTION}

Finance is playing an important role in any organization whatever the size of organization-large size, mid size and small size. A financially strong firm has leading position in the market. It can take initiatives for its firm. It can grab opportunity of the competitive market. Firms have many sources to raise funds to fulfill its long-term and short-term financial needs. Financial market is a great source to raise fund through equity and debt mode. Organizations are maintaining balance between equity and debt sources. Although, debt sources provides many privileges to firms but it is not easy to generate funds from debt market. In developed countries it has strong growth, through which organizations have ample of opportunity to get funds from market. They have broad base of debt instruments and investors. Both borrowers and investors are privileged with this market. Most of developing countries are also achieving this status but Indian debt market is still underdeveloped. Indian debt market has many restrictions and loopholes due to which it is not performing well like equity segment of financial market. Like equity market debt market also have two segment of trading-wholesale and retail debt market. The wholesale debt market for short-term and long-term debt instrument is well established but retail segment of it is not doing well. It is matter of concern that why is it, so. India is fast growing economy. Its development in all the areas is remarkable but it is lacking with this segment of development. It is required to take corrective action for this. In this research paper, researcher has tried to focus on those elements which hinders the growth of Indian corporate debt market.
Literature review: Financial market is source to accomplishes financing needs of the government and businesses operating in this environment. It permits corporates to raise funds externally matching to other sources which proves favourable for economic movement (Bondt, 2005). This system also channelise the savings and investments of the government, public and private sector entities and households. This also provides a channel for the both type of the investors-institutional and retail and borrowers (Machiraju, 2010). It expedite the trade-off, dodging, diversifying and amalgamating risk. A well-developed financial system can allocate resources, observe managers, exert corporate control, enable the exchange of goods and services. It played an important role in the growth of emerging market economies (Krishnan, 2011). It assists in managing risk for both equity and debt holders (Eichengreen and Luengnaruemitchai, 2004). A well-developed financial system have mature and healthy corporate bond market and comprehensive banking system that are working together (Davis, 2001; Beck and Levine, 2002).

Debt market has wide growth in international market. Developed countries have a well established and performing debt market. They have broad instrument base to trade in this market. Among developed countries US has giant presence in debt market. Its corporate debt market has shown dominance in outstanding volumes and total turnover as compared to other developed countries. It has world's largest and deepest bond market in both high-quality and low-quality bonds. Its secondary corporate debt market was reported highly liquid (Mukherjee, 2012). In early ages Japanese bond market was bank dominated. It started developing its corporate 
Int. Business Manage., 13 (7): 241-248, 2019

bond market in late 1990s. During the early development stage there was the need to improve its market design, market practices and credit analysis which was desirable for the market growth. But it also has a remarkable growth in its secondary debt market. Chinese debt market was also an emerging debt market. It had combination of both interbank and exchange traded system for the trading of debt securities. During early phase of 21 st century this market also had underdeveloped status. Institutional investors were the major player of interbank market while in exchange traded bond market medium and small corporates and individual investors were the foremost players. It has wider investor's base of both institutional and retail investors but suffered from several loopholes at the issuer's and investor's end.

India is a fast growing economy in the world. In early 20 th century it had developing financial market. In early 21 st century its equity market has achieved highest growth before recession in the market. But its debt market, especially, corporate debt market remained in meagre state. It contribution in the growth of economy was very less around $0.3 \% 0$ as compared to government debt market. There are several indicators that indicates sound development of a country's financial system. According to World Economic Forum, financial development was defined as "The factors, policies and institutions that lead to effective financial intermediation and markets and deep and broad access to capital and financial services" (as cited by Krishnan (2011)). On the other hand, financial development index has identified seven pillers of financial development that includes: factors, policies and institutions, financial intermediation and financial access to investors and borrowers (individuals and corporates) both (Financial Development Report, 2009).

Objective: On the critical evaluation of available literature on financial market, especially, on development of debt market researcher has found some gaps on development. Researcher has tried to identify few variables to study the development status of India's corporate debt market in retail segment. These variables were classified on macro-economic indicators and micro-economic indicators. Macroeconomic indicators of the economy like inflation rate, interest rate, monetary policy, exchange rate, tax policies, regulatory framework, regulatory policies and regulatory bodies operating in the debt market. Microeconomic indicators include liquidity, risk and return aspect of the market in retail segment.

\section{MATERIALS AND METHODS}

\section{Research hypothesis:}

- $\mathrm{H}_{\mathrm{O}_{1}}$ : macro (Economic, market and regulatory) and micro (liquidity, risk and return) indicators does not have influence on the development of retail market
Table 1: Reliability statistics

\begin{tabular}{lccl}
\hline Factors & $\begin{array}{c}\text { Cronbach alpha } \\
\text { co-efficient }\end{array}$ & No. of items & Results \\
\hline Macro-factors & 0.801 & 17 & Good \\
Micro-factors & 0.743 & 18 & Acceptable \\
\hline Sample size $=35$, Compiled by researcher through pilot testing result
\end{tabular}

In the preview of study, researcher has identified few variables that were not covered in earlier studies. They have influence on the growth and development of India's corporate debt market. To quantify these variable data has been collected by administering questionnaire on sample unit (investors) during April 2015 to November 2015. These questions were on the Likert's five point rating scale. According to thumb rule an appropriate sample size should be $50+8 \mathrm{k}$ where, ' $\mathrm{k}$ ' indicated predictors used for the study of model (Green as cited by Field (2009)). The researcher tried to tap the respondents but due to certain limitations researcher could not receive the desired responses from the sampling unit. The sampling area of the study was three cities of Utter Pradesh (UP) Allahabad, Kanpur and Lucknow.

Tests for reliability and validity: Cronbach alpha has been used by the researcher to test reliability of the tool. The reliability analysis was done with the SPSS 20.0 . The values shown in Table 1 reflecting that administered tool was highly reliable.

\section{RESULTS AND DISCUSSION}

\section{Data analysis and interpretation}

Descriptive analysis: Figure 1 shows that the brokers and financial advisors (respondents) operating in the financial market have good knowledge about the instruments and functioning of the market. Only $2 \%$ respondents have limited knowledge. They may not be aware about all the instruments available in market for the investment. They were also not much familiar from mechanism of financial market. Figure 2 indicates that $92 \%$ respondents were aware from the corporate debt securities. But they do not have in-depth knowledge about these securities. About $8 \%$ respondents have no clear cut idea about the corporate debt securities. They do not have skill to analyze risk and return associated with the corporate debt securities.

Figure 3 shows that $85 \%$ respondents were investing in the corporate debt securities. But these investments were for different motives and mostly in public sector companies. Figure 4 demonstrates that $65 \%$ respondents were investing in the debt securities via. mutual fund root. They were investors who have less risk bearing capacity and desire more return. About $22 \%$ respondents were investing in convertible bond/debentures. About $3 \%$ investors were investing in inflation indexed bonds to minimize the inflation risk associated with money. Rest was investing in non-convertible debentures and other short-term debt securities like $\mathrm{CP}$ and $\mathrm{CD}$, etc. 


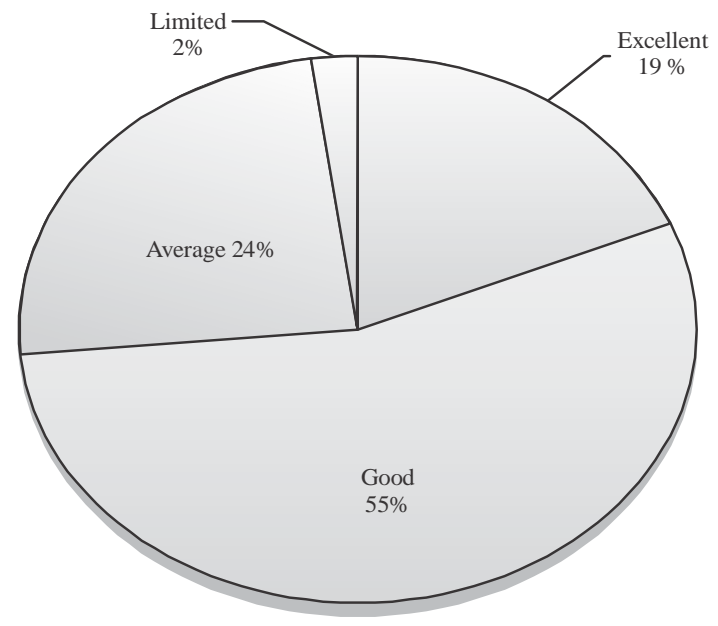

Fig. 1: Knowledge about the financial markets

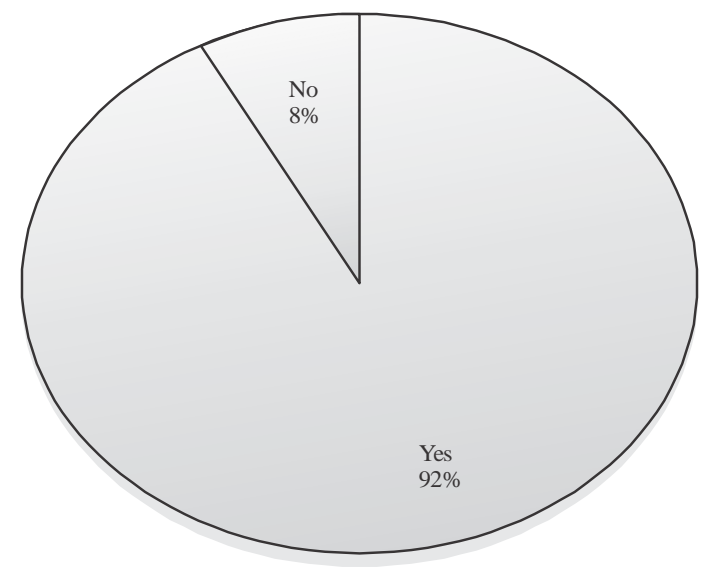

Fig. 2: Knowledge about corporate debt securities

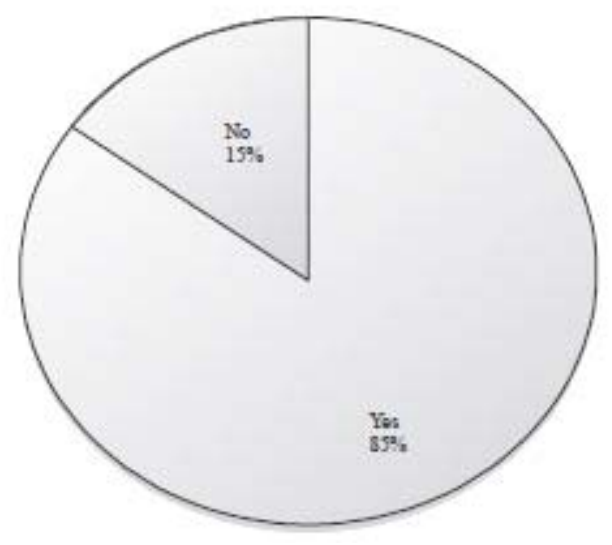

Fig. 3: Investments in corporate debt securities

Figure 5 indicates that $17 \%$ were investing below $10 \%$ of their financial allocation for investment. About

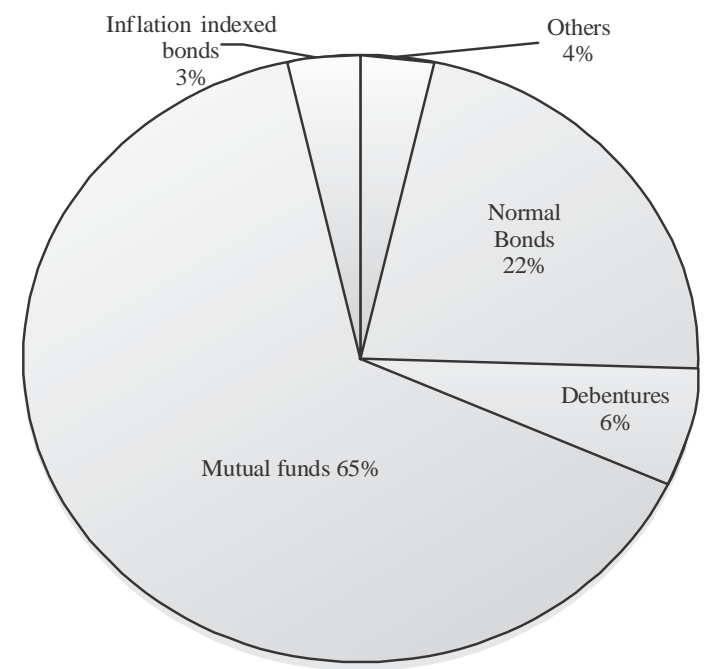

Fig. 4: Preference of debt instruments for investment

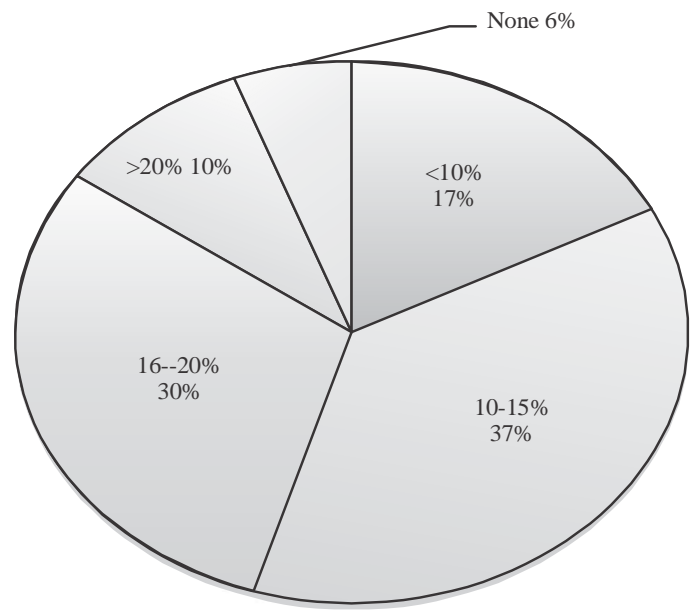

Fig. 5: Percentage of investment in corporate debt securities

$37 \%$ respondents were investing in corporate debt securities that were about $10-15 \%$ of their total investments. About 30\% investors were investing 16-20\% of their investment budget. About $10 \%$ investors were investing more than $20 \%$ of their total investment in the corporate debt securities. Only $6 \%$ investors had not opting corporate debt securities as investment choice in their financial plan. Figure 6 shows investment objectives of those investors who were investing in corporate debt securities. About $22 \%$ investors were investing in corporate debt securities having expectation of fixed earning. About $22 \%$ were investing for better return by taking benefit of market conditions. Only 5\% were investing for the tax saving motives. About $48 \%$ respondents were investing to accomplish their diversified motives. 


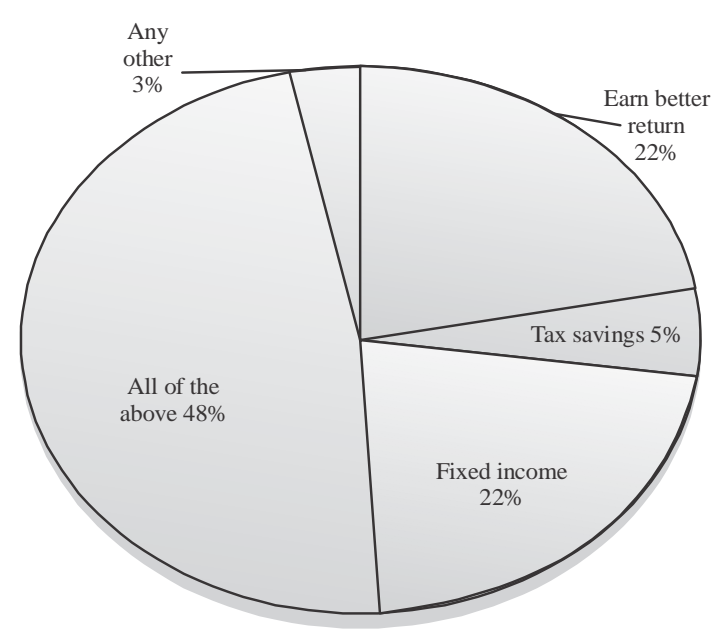

Fig. 6: Objective of investor's investments incorporate debt securities

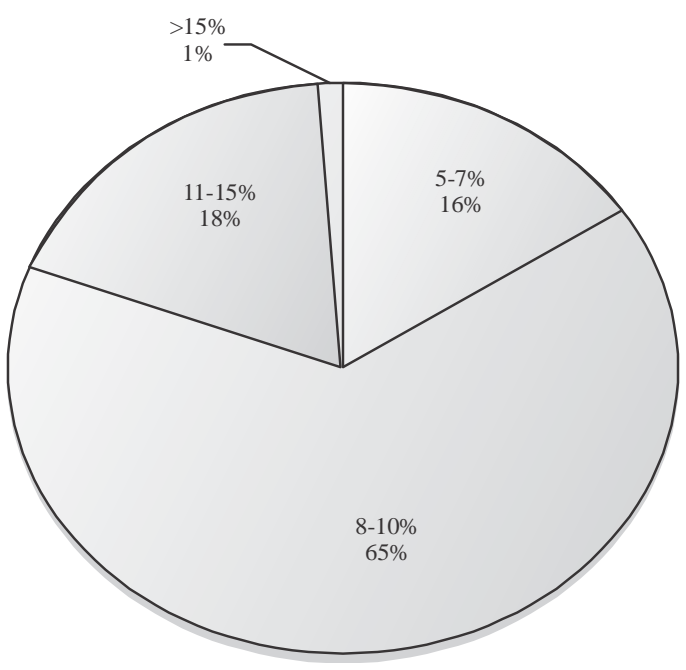

Fig. 7: Expected rate of return from corporate debt securities

Figure 7 demonstrates that $65 \%$ investors were expecting $8-10 \%$ return from debt securities while only $1 \%$ investors were expecting more than $15 \%$ returns from the investment in the debt securities. About 16\% investors have $5-7 \%$ return expectation. About 18\% investors were expecting $11-15 \%$ return from the same. This expectation may or may not be fulfilled because of interest rate fluctuations. Figure 8 shows that $58 \%$ investors were want to invest their money for 3-5 years while $23 \%$. Investors invest their money for the 5-10 years of time horizon. Only 19\% investors were investing for short-term, i.e., for 1-3 years. Figure 9 displays that $25 \%$ of investors preferred to invest in corporate debt securities of PSU while only 13\% have preference in private companies. About $59 \%$ of the

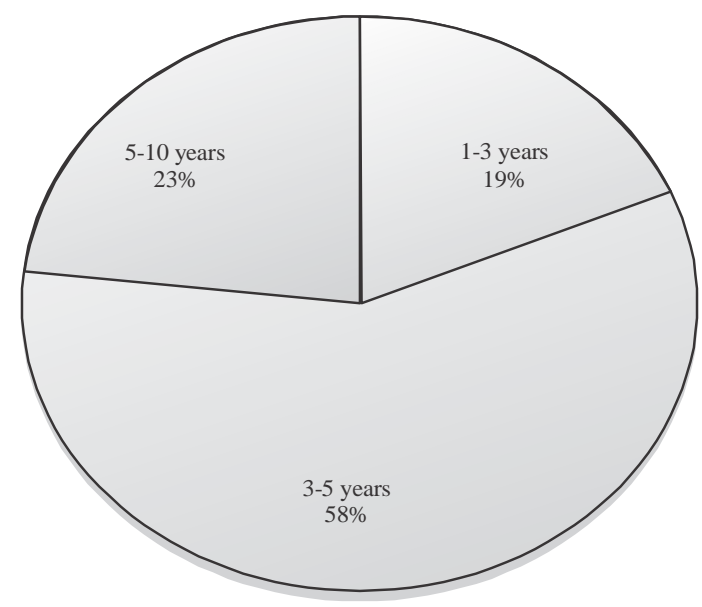

Fig. 8: Average time horizon of investor's investments

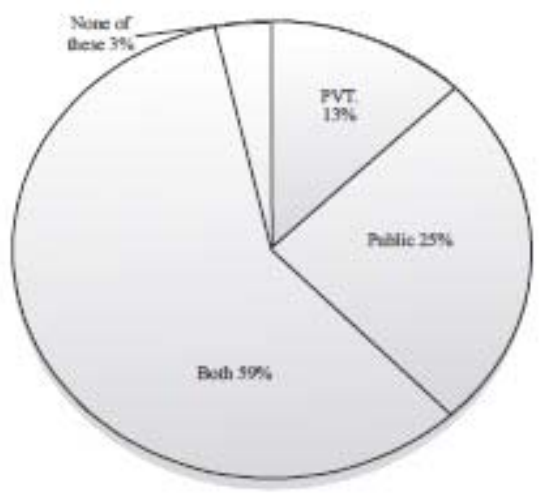

Fig. 9: Investor's preference of companies to invest in debt securities

investors were diversifying their investment in both PSU and private companies to manage risk associated with the corporate debt securities. Only 3\% investors were those who were not investing any of companies directly. They may be either not investing in corporate debt securities or investing through different mode. Figure 10 demonstrates that $78 \%$ investors have preference to invest in AAA rated corporate debt securities. They were having low risk bearing capability. Only $2 \%$ investors were investing in $\mathrm{BBB}$ rated securities. They may have high risk bearing capacity to invest in low investment grade securities. About 11 and $7 \%$ were investing in $\mathrm{AA}$ and $\mathrm{A}+$ rated securities. Figure 11 shows that $42 \%$ investors preferred to purchase debt securities from intermediate channel members like brokers, $16 \%$ were approaching to companies for the same. However, $8 \%$ were directly operating through stock exchanges and $6 \%$ from the 


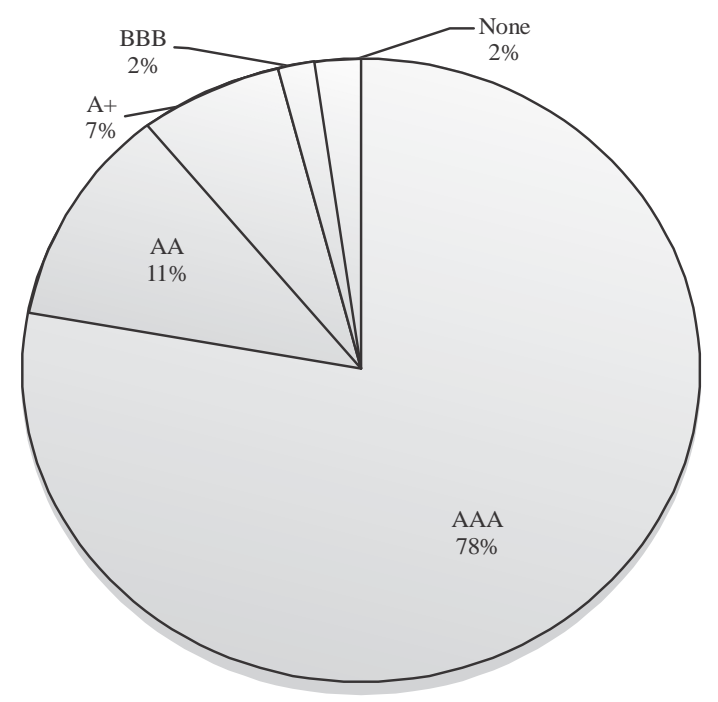

Fig. 10: Investor's preference to invest in companies rated debt securities

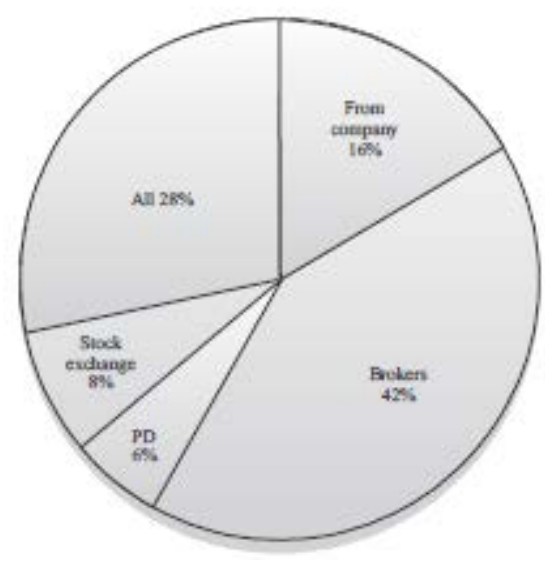

Fig. 11: The source of corporate debt securities purchase

primary dealers. They were those investors who purchase securities in bulk not only for investment motives but also for taking benefits of less transparent market. About 28\% investors were investing through all medium depends upon the accessibility of channel.

Factor analysis-Principal Component Analysis (PCA): Factor analysis is a data reduction technique. It can be performed through principal component analysis and exploratory component analysis. To explore the significant items from the questionnaire the researcher has conducted PCA on 35 items to test validity of questionnaire. The results were generated in the form of
Table 2: KMO and Bartlett's test

\begin{tabular}{lr}
\hline Bartlett's test & Values \\
\hline Bartlett's test of sphericity Kaiser-Meyer-Olkin (KMO) & \\
Measure of sampling adequacy & 0.649 \\
Approx. $\chi^{2}$ & 2487.456 \\
df & 595.000 \\
Sig. & 0.000 \\
\hline
\end{tabular}

$\mathrm{KMO}$ and Bartlett's test, total variance and component matrix. Table 2 demonstrated the KMO and Bartlett's test. KMO measure of sampling adequacy explained the standard sample size to perform PCA. The analyzed $\mathrm{KMO}$ value was 0.649 which was greater the acceptable limit 0.50 (Field, 2009). Bartlett's test of Sphericity $\left[\left(\chi^{2}\right)-(\mathrm{df})-595\right]=2487.456$ and significant p-value $(0.000<0.01)$ supports PCA. On running PCA researcher also got total variance matrix which represented eigen-values of the component as per the Kaiser's criterion. The components having more than one eigen-value collectively explained the common variance among the components. Table 3 demonstrated that all 35 items grouped into 10 components. These items have higher factor loadings. Out of 35 items $68.339 \%$ variances were explained by 11 components. Table 4 showed the component score matrix. In this matrix, items having factor loading more than 0.40 were taken into consideration to form new group of selected items. The items having value below 0.40 were dropped. This process reduced 35 items into 11 components. These 11 components were further grouped into five components. These components were named-market structure and policies regulatory structure market liquidity market risk and market return.

Table 4 represented the descriptive statistics of data set of variables affecting the retail debt market. This Table 5 described the range, mean, standard deviation, skewness and kurtosis of the above mentioned data set. The values of skewness and kurtosis depicted the non-normal distribution of data set.

\section{Normality test:}

- $\mathrm{H}_{\mathrm{O} 1 \mathrm{a}}$ : data series of explanatory variables (Market structure and policies, regulatory framework, risk and return) and dependent variable (Liquidity) are normal

Table 5 represented results of normality of the data. Kolmogorov-Smirnova showed that respective p-values $(0.000<0.01,0.000<0.01,0.000<0.01,0.000<0.01$ and $0.000<0.01$ ) were significant at $1 \%$ level of significance for the explanatory variables (Market structure and policies, regulatory framework, risk and return) and dependent variable (Liquidity). This supported the rejection of null Hypothesis $\left(\mathrm{H}_{\mathrm{O} 12}\right)$. This means data series were non-normal. Shapiro-Wilk test statistics also confirms that data series were non-normal for the above 
Int. Business Manage., 13 (7): 241-248, 2019

Table 3: Component score coefficient matrix

\begin{tabular}{|c|c|c|c|c|c|c|c|c|c|}
\hline \multirow[b]{2}{*}{ Components } & \multicolumn{3}{|c|}{ Initial eigen values } & \multicolumn{3}{|c|}{ Extraction sums of squared loadings } & \multicolumn{3}{|c|}{ Rotation sums of squared loadings } \\
\hline & Total & Variance $(\%)$ & Cumulative $(\%)$ & Total & Variance $(\%)$ & Cumulative $(\%)$ & Total & Variance $(\%)$ & Cumulative $(\%)$ \\
\hline 1 & 5.636 & 16.103 & 16.103 & 5.636 & 16.103 & 16.103 & 3.098 & 8.852 & 8.852 \\
\hline 2 & 3.294 & 9.413 & 25.516 & 3.294 & 9.413 & 25.516 & 2.551 & 7.288 & 16.141 \\
\hline 3 & 2.542 & 7.264 & 32.780 & 2.542 & 7.264 & 32.780 & 2.306 & 6.588 & 22.729 \\
\hline 4 & 2.255 & 6.441 & 39.221 & 2.255 & 6.441 & 39.221 & 2.241 & 6.403 & 29.132 \\
\hline 5 & 1.932 & 5.520 & 44.742 & 1.932 & 5.520 & 44.742 & 2.222 & 6.348 & 35.480 \\
\hline 6 & 1.746 & 4.987 & 49.729 & 1.746 & 4.987 & 49.729 & 2.145 & 6.128 & 41.608 \\
\hline 7 & 1.697 & 4.850 & 54.578 & 1.697 & 4.850 & 54.578 & 2.140 & 6.115 & 47.723 \\
\hline 8 & 1.277 & 3.649 & 58.227 & 1.277 & 3.649 & 58.227 & 2.082 & 5.948 & 53.671 \\
\hline 9 & 1.253 & 3.581 & 61.808 & 1.253 & 3.581 & 61.808 & 1.778 & 5.080 & 58.752 \\
\hline 10 & 1.208 & 3.451 & 65.259 & 1.208 & 3.451 & 65.259 & 1.686 & 4.816 & 63.568 \\
\hline 11 & 1.078 & 3.080 & 68.339 & 1.078 & 3.080 & 68.339 & 1.670 & 4.772 & 68.339 \\
\hline
\end{tabular}

Extraction method: principal component analysis

Table 4: Descriptive statistics of retail market variables

\begin{tabular}{lllllcc}
\hline Variables & Min. & Max. & Mean & SD & Skewness & Kurtosis \\
\hline Market structure and policies & 2.33 & 4.67 & 3.8079 & 0.49443 & -0.445 & 0.099 \\
Regulatory framework & 1.33 & 5 & 3.7797 & 0.74436 & -0.808 & 1.068 \\
Liquidity & 2 & 4.83 & 3.6563 & 0.51252 & -0.608 & 1.097 \\
Risk & 1.67 & 5 & 3.7137 & 0.59643 & -0.143 & 0.061 \\
Return & 2.29 & 4.86 & 3.7651 & 0.50857 & -0.28 & 0.244 \\
No. of observations & 177 & 177 & 177 & 177 & 177 & 177 \\
\hline
\end{tabular}

Table 5: Results of normality tests

\begin{tabular}{|c|c|c|c|c|c|c|}
\hline \multirow[b]{2}{*}{ Variables } & \multicolumn{3}{|c|}{ Kolmogorov-Smirnov ${ }^{\mathrm{a}}$} & \multicolumn{3}{|c|}{ Shapiro-Wilk } \\
\hline & Statistic & df & Sig. & Statistic & df & Sig. \\
\hline Market structure and policies & 0.114 & 177 & 0.000 & 0.967 & 177 & 0.000 \\
\hline Regulatory framework & 0.129 & 177 & 0.000 & 0.934 & 177 & 0.000 \\
\hline Risk & 0.114 & 177 & 0.000 & 0.965 & 177 & 0.000 \\
\hline Return & 0.096 & 177 & 0.000 & 0.977 & 177 & 0.005 \\
\hline Liquidity & 0.126 & 177 & 0.000 & 0.957 & 177 & 0.000 \\
\hline
\end{tabular}

${ }^{a}$ Lilliefors significance correction

Table 6: Correlation matrix

\begin{tabular}{|c|c|c|c|c|c|}
\hline Variables & Market structure and policies & Regulatory framework & Liquidity & Risk & Return \\
\hline Market structure and policies & 1 & & & & \\
\hline Regulatory framework & $0.426^{* * *}$ & 1 & & & \\
\hline Liquidity & $0.352^{* * *}$ & $0.265^{\text {**** }}$ & 1 & & \\
\hline Risk & $0.539^{* * *}$ & $0.217^{\text {*** }}$ & $0.243^{\text {*** }}$ & 1 & \\
\hline Return & $0.413^{\text {*** }}$ & $0.308^{* * *}$ & $0.567^{* * * 6}$ & 0.505 & 1 \\
\hline
\end{tabular}

Analysis results compiled by researcher; ${ }^{* *}$ Significant at $1 \%$ level

Table 7: Model summary

\begin{tabular}{|c|c|c|c|c|c|c|c|c|}
\hline \multirow[b]{2}{*}{$\mathrm{R}$} & \multirow[b]{2}{*}{$\mathrm{R}^{2}$} & \multirow[b]{2}{*}{ Adjusted $\mathrm{R}^{2}$} & \multirow[b]{2}{*}{ SE of the estimate } & \multicolumn{5}{|c|}{ Change statistics } \\
\hline & & & & $\mathrm{R}^{2}$ change & F-ratio change & df1 & df2 & Sig. F change Durbin-Watson \\
\hline $0.594^{\mathrm{a}}$ & 0.353 & 0.338 & 0.41698 & 0.353 & 23.473 & 4 & 172 & $\begin{array}{ll}0.000 & 1.684 \\
\end{array}$ \\
\hline
\end{tabular}

${ }^{\mathrm{a}}$ Significant values

said variables because all the respective p-values $(0.000<0.01,0.000<0.01,0.000<0.01,0.005<0.01$ and $0.000<0.01$ ) were significant at $1 \%$ level of significance. This also evidenced that null Hypothesis $\left(\mathrm{H}_{\mathrm{O} 1 \mathrm{a}}\right)$ got rejected. This suggested the non-parametric test for further analysis.

Multiple regression analysis: Table 6 and 7 represented the model fit summary of dependent and explanatory variables. R-value (0.594) explained that liquidity has strong correlation with the market structure and policies, regulatory framework, risk and return. $\mathrm{R}^{2}$ (0.353) indicated that market structure and policies, regulatory framework, risk and return were accounted only $35.3 \%$ variations in the liquidity of retail debt market. Adjusted $R^{2}(0.338)$ explained the adjusted variation for the fitness of model. This elucidated that, if the model will generalise for whole population then there will be only $1.4 \%$ variation in the fitness of model with the given set of variables. F-ratio (23.473) described the change in the $\mathrm{R}$-value on adding any new variable. It is significant as its p-value $(0.000<0.01)$ at $1 \%$ significance level. Durbin Watson (DW) value (1.684) was closure to 2 which explained that all the assumption for the model fitness was almost met. 
Int. Business Manage., 13 (7): 241-248, 2019

Table 8: ANOVA $^{a}$

\begin{tabular}{lccccc}
\hline Models & Sum of squares & df & Mean square & F-values & Sig. \\
\hline Regression & 16.325 & 4 & 4.081 & 23.473 & $0.000^{6}$ \\
Residual & 29.906 & 172 & 0.174 & - & - \\
Total & 46.231 & 176 & - & - & - \\
\hline
\end{tabular}

${ }^{a}$ Dependent variable: Liquidity, ${ }^{6}$ Predictors: (Constant), return, regulatory framework, risk, market structure and policies

Table 9: Coefficients ${ }^{\mathrm{a}}$

\begin{tabular}{|c|c|c|c|c|c|c|c|}
\hline \multirow[b]{2}{*}{ Variables } & \multicolumn{3}{|c|}{ Unstandardized coefficients Standardized } & \multirow[b]{2}{*}{ t-values } & \multirow[b]{2}{*}{ Sig. } & \multicolumn{2}{|c|}{ Co-linearity statistics } \\
\hline & B & $\mathrm{SE}$ & $(\beta)$ & & & Tolerance & VIF \\
\hline$\overline{\text { (Constant) }}$ & 1.185 & 0.288 & & 4.107 & 0.000 & & \\
\hline $\begin{array}{l}\text { Market Structure and } \\
\text { Policies (MSP) }\end{array}$ & 0.188 & 0.082 & 0.181 & 2.291 & 0.023 & 0.601 & 1.664 \\
\hline Regulatory Framework (RF) & 0.034 & 0.047 & 0.049 & 0.718 & 0.474 & 0.792 & 1.262 \\
\hline Return (RE) & 0.553 & 0.074 & 0.548 & 7.451 & 0.000 & 0.694 & 1.441 \\
\hline Risk (RI) & -0.122 & 0.068 & -0.142 & -1.809 & 0.072 & 0.609 & 1.642 \\
\hline
\end{tabular}

${ }^{\mathrm{a}}$ Dependent variable: Liquidity (LI)

Table 8 represented result of MANOVA for the set of variables. The p-value of F-ratio $(0.000<0.01)$ was significant at $1 \%$ significance level that explained the preciseness of model fitness for the given set of dependent (liquidity) and explanatory variables (return, regulatory framework, risk, market structure and policies):

$$
\begin{aligned}
& \mathrm{Yi}=\mathrm{b} 0+\mathrm{b} 1 \mathrm{Xi} 1+\mathrm{b} 2 \mathrm{Xi} 2+, \ldots,+\mathrm{bnXnD}+\varepsilon \mathrm{i} \\
& \mathrm{LI}_{\mathrm{i}}=\mathrm{b} 0+\mathrm{b}_{1 M S P}+\mathrm{b} 2 \mathrm{RF}_{\mathrm{i}}+\mathrm{b} 3 \mathrm{RE}_{\mathrm{i}}+\mathrm{b} 4 \mathrm{RI}_{\mathrm{i}} \\
& \mathrm{LI}_{\mathrm{i}}=1.185+0.188 \mathrm{MSP}_{\mathrm{i}}+0.034 \mathrm{RF}_{\mathrm{i}}+ \\
& 0.553 \mathrm{RE}_{\mathrm{i}}-0.122 \mathrm{RI}_{\mathrm{i}}
\end{aligned}
$$

Table 9 demonstrated the coefficient of individual explanatory variables. Unstandardized coefficient (B) described the degree of change in the dependent variable due to change of $1 \%$ in explanatory variable. Equation 1 explained that on change of $1 \%$ in MSP, liquidity of the retail market will vary by $137.3 \%$. This also explained that change of $1 \%$ in $\mathrm{RF}$ and $\mathrm{RE}$, liquidity of the retail market will vary positively 121.9 and $173.8 \%$, respectively. However, change of $1 \%$ in RI, liquidity of the retail market will change negatively by $130.7 \%$. Standardized $\beta$ coefficient described the variation in the above mentione dequation values due to change in sample or applied on whole population. The average value of Variance in Factor (VIF) was greater to 1. So, it may have biasness in the estimated regression equation. Tolerance values were fairly high which showed that estimated equation has potential to explain the relationship among the variables and co-linearity was not an issue for the equation.
Findings: Analysis of data regression coefficient $\left(\mathrm{R}^{2}=0.353\right)$ reflects that estimated model for the taken set of macro-economic variables and micro-economic variables describes only $35.3 \%$ of fitness. This may be due to standard error generated for sample size and some unobserved estimated variables. However, F-statistics F $=23.473(\mathrm{p}<0.01)$ reveals that all the independent macro-economic and micro-economic variables jointly affect the liquidity of the retail debt market. Lack of liquidity is the major factor that inhibits growth and development of Indian retail corporate debt market. Improvement in this factor would enhance the development of this market and may prove supporting hand of financing in the country, apart from the existing financial system. Model $\mathrm{Vb}$ explained that risk have negative impact on the liquidity of the market while MSP, RF and $\mathrm{RE}$ have positive influence on the development of retail corporate debt market by enhancing the liquidity of the market. Batten and Szilagyi (2003) has explained that tax system of the country as a part of policy structure have impact on the liquidity of the market. Retail corporate debt market also suffers from the depth of investor's base (Gandhi, 2015; Patil, 2001). Its main reason is the lack of financial awareness about the corporate long-term debt instrument (bonds/debentures) as an investment avenue. Social interaction has positive influences on the households investment in debt securities (Brown et al., 2015). Thomas (2006) has supported that on reducing interest rate may enhance liquidity of the market. Lejot et al. (2006) also support that for the development of domestic bond market government has to establish required regulatory network to eliminate and discrepancies. Investors seeks market signals to invest in bonds/debentures. 


\section{CONCLUSION}

The study has shown that primary and wholesale corporate debt market is well developed. This market has institutional participation and not works for the retail investors. There are several loopholes in market structure and regulatory frameworks. Higher risk and low return negatively induced the liquidity of this market. Market design and regulatory frameworks are positively stimulus for growth and development of corporate debt market for retail and small investors. Policy reforms are also an important aspect which needs to do for growth of market. To catch the attention of investors in this market their awareness about the market and instrument is required to enhance. Pooling of retail funds into SPVs may catch retail investor's interest.

\section{ACKNOWLEDGEMENT}

This research was supported by University Grant Commission, New Delhi (India). I am thankful to my supervisors Dr. Ambalika Sinha (professor, MNNIT Allahabad) and Dr. Ravindra Tripathi (associate professor, MNNIT Allahabad) who provided insight and expertise that greatly assisted the research.

I am also thankful to the research development committee for their valuable comments on my research. These suggestions helped me to improve my research paper. I am also expressing my gratitude to the reviewer of the study for giving their valuable comments on an earlier version of the manuscript.

\section{REFERENCES}

Batten, J. and P. Szilagyi, 2003. Why Japan needs to develop its corporate bond market. Intl. J. Econ. Bus., 10: 83-108.

Beck, T. and R. Levine, 2002. Industry growth and capital allocation: Does having a market-or bank-based system matter?. J. Financial Econ., 64: 147-180.

Bondt, G.D., 2005. Determinants of corporate debt securities in the euro area. Eur. J. Finance, 11: 493-509.
Brown, S., P. Ghosh and K. Taylor, 2015. Household finances and social interaction: Bayesian analysis of household panel data. Rev. Income Wealth, 62: $467-488$

Davis, E.P., 2001. Multiple avenues of intermediation, corporate finance and financial stability. MBA Thesis, International Monetary Fund, Washington, DC., USA.

Eichengreen, B. and P. Luengnaruemitchai, 2004. Why doesn't Asia have bigger bond markets? NBER Working Paper No. 10576, National Bureau of Economic Research, Cambridge, Massachusetts, USA. https://www.nber.org/papers/w10576

Field, A., 2009. Discovering Statistics Using SPSS. 3rd Edn., Sage Publications Ltd., London, UK., ISBN: 978-1-84787-907-3, Pages: 822.

Gandhi, R., 2015. Corporate debt market: What needs to be done a reaffirmation. CARE Ratings Debt Market Summit, Mumbai, India. https://www.bis.org/ review/r150324d.pdf

Krishnan, K.P., 2011. Financial development in emerging markets: The Indian experience. ADBI Working Paper 276, Asian Development Bank Institute, Tokyo, Japan. https://www.adb. org/sites/default/files/publication/156131/adbi-wp 276.pdf

Lejot, P., D. Arner and L. Qiao, 2006. Missing links: Regional reforms for Asia's bond markets. Asia Pac. Bus. Rev., 12: 309-331.

Machiraju, H.R., 2010. Indian Financial System. 4th Edn., Vikas Publishing House Private Limited, New Delhi, India, ISBN:9788125939818, Pages: 458.

Mukherjee, K.N., 2012. Corporate bond market in India: Current scope and future challenges. MPRA Paper No. 42478, National Institute of Bank Management, Pune, India. https://mpra.ub.uni-muenchen.de/ 42478/1/MPRA paper_42478.pdf

Patil, R.H., 2001. Debt market reforms. Econ. Political Weekly, 36: 802-805.

Thomas, S., 2006. Resilience of liquidity in Indian securities markets. Econ. Political Weekly, 41: 3452-3454. 